\title{
Desain Perencanaan Pelaksanaan Pembelajaran Pendidikan Agama Islam Daring dengan Kurikulum Darurat
}

\author{
Widy Astuty \\ Universitas Islam Negeri Profesor Kiai Haji Saifuddin Zuhri Purwokerto \\ Email: widy4142@gmail.com

\begin{abstract}
Abdul Wachid Bambang Suharto
Universitas Islam Negeri Profesor Kiai Haji Saifuddin Zuhri Purwokerto

Email: abdulwachidbs33@gmail.com
\end{abstract}

Received: February 22, 2021 | Accepted: June 13, 2021

\begin{abstract}
Teaching activities are the process of conveying knowledge information from teachers to learners. The success of the learning process will be achieved if it is based on established learning planning and healthy learning conditions. During the current Covid-19 pandemic, learning patterns have changed. The government enforces an emergency curriculum with the aim of continuing the learning process properly. The learning system changed which originally immediately became an online system. Of course, this also requires all teachers, including PAI teachers, to innovate in planning learning with an online system. This research was conducted to find out the process of how PAI teachers can design PAI learning planning that is in accordance with the pandemic situation based on the emergency curriculum that has now been implemented. The method is done by using descriptive qualitative. The techniques used are observation, interview and documentation directly to the process of designing learning planning by PAI teachers at SD N 1 Pageraji in Grade IV.
\end{abstract}

\begin{abstract}
Abstrak
Kegiatan mengajar merupakan proses penyampaian informasi pengetahuan dari guru kepada peserta didik. Keberhasilan proses pembelajaran akan diraih apabila dilandaskan dengan perencanaan pembelajaran yang mapan dan kondisi pembelajaran yang sehat. Di masa pandemi Covid-19 yang sedang terjadi saat ini telah mengubah pola pembelajaran. Pemerintah memberlakukan kurikulum darurat dengan tujuan agar proses pembelajaran terus berlangsung dengan baik. Sistem pembelajaran berubah
\end{abstract}


yang semula langsung menjadi system daring. Tentu hal ini juga menuntut semua guru, termasuk guru PAI untuk melakukan inovasi dalam menyusun perencanaan pembelajaran dengan sistem daring. Penelitian ini dilakukan untuk mengetahui proses bagaimana guru PAI dapat mendesain perencanaan pembalajaran PAI yang sesuai dengan situasi pandemik berdasarkan kurikulum darurat yang saat ini telah diberlakukan. Adapun metode yang dilakukan yaitu dengan menggunakan deskriptif kualitatif. Teknik yang digunakan adalah pengamatan, wawancara dan dokumentasi secara langsung terhadap proses mendesain perencanaan pembelajaran oleh guru PAI di SD N 1 Pageraji pada Kelas IV.

\section{Keywords}

Learning planning design, online, emergency curriculum

\section{Pendahuluan}

Pembelajaran merupakan sebuah proses yang sistematis dan sistemik yang terdiri dari beberapa komponen, yaitu terdiri dari: pendidik, kurikulum/program, peserta didik, proses, output, fasilitas dan strategi. Masing-masing komponen tersebut tidak berjalan sendiri-sendiri, tetapi berjalan secara teratur, saling bergantung, komplementer dan berkesinambungan (Farida, 2019:2). Untuk itu perlu adanya persiapanpersiapan yang terencana dengan matang. Rancangan dan pengelolaan pembelajaran yang baik perlu dikembangkan untuk mencapai tujuan-tujuan pembelajaran yang diharapkan. Hal ini tentu saja menuntut guru sebagai salah satu komponen untuk dapat merancang dan mengelola pembelajaran di antaranya adalah dengan menyusun perencanaan pembelajaran, berinteraksi dengan peserta didik, mengelola kelas, mendayagunakan sumber dan media belajar, serta melakukan penilaian.

Keberhasilan suatu proses pembelajaran tentunya diawali dengan perencanaan yang sangat matang. Perencanaan pembelajaran merupakan suatu ide dari orang yang merancangnya, tentang bentuk-bentuk pelaksanaan proses pembelajaran yang akan dilaksanakan (Hakim, 2011:1). Perencanaan merupakan salah satu syarat mutlak bagi setiap kegiatan pengelolaan. Tanpa perencanaan, pelaksanaan suatu kegiatan akan mengalami kesulitan dan bahkan kegagalan dalam mencapai tujuan yang diinginkan (Majid, 2008:62). Jika perencanaan dilakukan dengan baik, sesungguhnya setengah dari keberhasilan sudah tercapai, selanjutnya setengahnya kemudian ditentukan oleh pelaksanaan dari pembelajaran tersebut. Maksudnya, meskipun perencanaan sudah disusun dengan baik dan sistematis tetapi bila dalam pelaksanaannya tidak sesuai dengan 
perencanaan, kemungkinan tujuan pembelajaran tidak akan tercapai. Oleh karena itu, perencanaan yang baik dan pelaksanaan yang tepat akan sangat menentukan keberhasilan proses pembelajaran.

Rencana pelaksanaan kegiatan pembelajaran sangat menunjang dalam upaya peningkatan mutu pendidikan. Hal ini diperuntukkan agar proses pembelajaran tersusun dan terarah sesuai dengan tujuan pembelajaran yang akan dicapai dalam sebuah satuan pendidikan. Adapun defenisi dari perencanaan pembelajaran atau biasa disebut rencana pelaksanan pembelajaran (RPP) adalah rancangan pembelajaran mata pelajaran per unit yang akan diterapkan guru dalam pembelajaran di kelas (Baroroh, 2017). Perencanaan teramat dibutuhkan sebelum pelaksanaan proses pembelajaran PAI dilaksanakan.

Berdasarkan hasil dari sebuah penelitian tentang berbagai manfaat bagi guru dalam memahami fungsi perencanaan pembelajaran dalam proses belajar mengajar, yaitu: (a) sebagai petunjuk kegiatan dalam mencapai tujuan, (b) sebagai pola dasar mengatur tugas dan wewenang bagi setiap unsur yang terlibat dalam kegiatan, (c) sebagai pedoman kerja bagi setiap unsur, baik unsur guru maupun unsur peserta didik, (d) sebagai alat ukur efektif tidaknya suatu pekerjaan sehingga setiap saat diketahui ketepatan dan kelambatan kerja, (d) sebagai bahan penyusunan data agar terjadi keseimbangan kerja, dan (e) untuk menghemat waktu, tenaga, alat-alat dan biaya (Baroroh, 2017).

Penelitian lain mengatakan bahwa dengan perencanaan yang baik dan matang memiliki kegunaan yang banyak terutama dalam proses pembelajaran, yakni terwujudnya efektivitas dan efisiensi dalam proses pembelajaran (Hidayat dan Syafe'i, 2018). Perencanaan disusun supaya pembelajaran yang dilakukan bisa efektif dan efisien. Seorang pendidik tidak hanya mentransfer ilmu saja saat proses pembelajaran, tetapi bagaimana caranya seorang pendidik tersebut bisa menurunkan dari ilmu menjadi sikap dan diamalkan dalam kehidupan sehari-hari.

Proses pembelajaran pada kondisi saat ini, di mana dunia pendidikan dalam masa pandemik akibat Covid-19 dirasa sangat menyulitkan bagi semua komponen pembelajaran. Sementara itu pemenuhan hak peserta didik untuk mendapatkan layanan pendidikan merupakan kewajiban bagi seluruh komponen satuan pendidikan dengan prioritas utama kesehatan dan keselamatan peserta didik serta seluruh warga satuan pendidikan. Sebagai salah satu upaya untuk mencegah meluasnya penularan Covid-19, Pemerintah telah menetapkan kebijakan dengan mengeluarkan Surat Edaran nomor 4 tahun 2020 yang berisi tentang Pelaksanaan Kebijakan Pendidikan dalam Masa Darurat Penyebaran Covid-19. 
Kondisi ini tentu menimbulkan dampak yang sangat terasa, terutama adalah beban psikologis yang harus ditanggung oleh guru, peserta didik, dan orang tua. Bagi guru, mereka harus merumuskan perencanaan pembelajaran yang sesuai, mulai dari kompetensi dasar hingga evaluasi yang sesuai dengan pembelajaran daring dan dapat memenuhi tujuan pembelajaran yang telah ditetapkan dengan baik. Bagi orang tua, terutama bagi mereka yang biasa sibuk dengan pekerjaannya di luar rumah, mendampingi anaknya untuk melakukan proses pembelajaran daring tentu akan menjadi tambahan beban tersendiri. Demikian juga dengan problem psikologis peserta didik. Mereka sudah terbiasa belajar bertatap muka langsung dengan guru-guru dan teman-teman sekelas, namun kondisi saat ini harus terbiasa belajar mandiri melalui berbagai media yang mungkin terasa asing bagi mereka.

Bagi guru sebagai pemegang kunci utama keberhasilan dalam pembelajaran, belajar daring memiliki dampak yang lebih komplek. Perubahan sistem belajar yang mengharuskan guru untuk mampu menyiapkan perangkat pembelajaran dengan strategi yang sesuai dengan kebutuhan. Guru dituntut untuk meningkatkan kemampuan profesionalitasnya yaitu dalam penguasaan materi, metode, dan media pembelajaran agar dapat mencapai tujuan pendidikan yang telah ditentukan. Jika pelaksanaan tidak direncanakan dengan baik, dapat berakibat pada menurunnya kualitas pendidikan.

Saat ini proses pembelajaran dilaksanakan dari rumah atau yang disebut dengan pembelajaran daring/pembelajaran jarak jauh (PJJ). Situasi pembelajaran daring yang dilaksanakan saat ini tentunya berbeda dengan pembelajaran saat tatap muka. Banyak sekali hal yang berubah. Mulai dari tempat belajar yang semula di bangku sekolah, kini belajar hanya dari rumah. Cara belajar yang sebelumnya tatap muka, kini harus terkoneksi dengan internet. Dalam pelaksanaannya, belajar daring sampai sekarang menimbulkan banyak permasalahan bagi orang tua, siswa dan guru. Permasalahan yang sering ditemukan pada sistem pembelajaran daring antara lain: keterbatasan penguasaan teknologi informasi oleh guru dan peserta didik, sarana dan prasarana yang kurang memadai, akses internet yang terbatas, dan kurang siapnya penyediaan anggaran. Yang tidak kalah penting dari permasalahan tersebut adalah kehadiran peserta didik sulit terkontrol. Tingkat kehadiran peserta didik jauh menurun. Hal ini disebabkan oleh faktor dalam diri siswa sendiri yang kurang disiplin serta kontrol orang tua yang kurang optimal. Sehingga belajar daring dinilai kurang efektif dan interaktif dibandingkan dengan belajar secara luring.

Dampak dan permasalahan di atas terjadi pada setiap mata pelajaran, tidak terkecuali mata pelajaran Pendidikan Agama Islam yang merupakan mata pelajaran utama yang banyak melibatkan pemahaman 
konsep dan praktik. Pendidikan Agama Islam diartikan sebagai proses trans-internalisasi pengetahuan dan nilai Islam kepada peserta didik melalui upaya pengajaran, pembiasaan, bimbingan, pengusahaan, pengawasan, pengarahan, dan pengembangan potensi-potensinya, guna mencapai keselarasan dan kesempurnaan hidup di dunia dan akhirat, jasmani dan rohani (Nafis, 2011). Sementara, Muhaimin memaknai Pendidikan Agama Islam sebagai upaya mendidikkan agama Islam atau ajaran Islam dan nilai-nilainya agar menjadi pandangan dan sikap hidup seseorang (Mahmudi, 2019). Aktivitas mendidik agama Islam bertujuan untuk membantu seseorang atau sekelompok peserta didik dalam menanamkan dan/atau menumbuhkembangkan ajaran Islam dan nilainilainya untuk dijadikan sebagai pandangan hidupnya (Mahmudi, 2019). Keberhasilan dalam mencapai tujuan PAI tersebut di antaranya disebabkan oleh kemampuan seorang guru dalam menyiapkan strategi pembelajaran yang sesuai (Sukmadinata, 2006:191).

Dari kondisi nyata yang sedang terjadi, menjadi dasar pertimbangan bagi guru khususnya di SDN 1 Pageraji untuk membuat rancangan pembelajaran PAI daring yang tepat. Langkah ini dilakukan agar seluruh peserta didik dapat belajar dengan baik, serta lebih mudah bagi orang tua dalam mendampingi anak-anak mereka dalam belajar. Dengan demikian, diharapakan agar tujuan pembelajaran dapat dicapai dengan baik pula.

\section{Metode}

Metode yang digunakan dalam penelitian ini adalah deskriptif kualitatif. Jenis penelitian ini berupa penelitian lapangan (field research), yaitu penelitian yang dilakukan dengan terjun ke lapangan untuk mencari dan meneliti data (Sugiyono, 2010:13). Penelitian deskriptif merupakan sebuh metode penelitian yang ditunjukkan untuk menggambarkan fenomena-fenomena yang ada, yang berlangsung saat ini dan saat lampau. Penelitian deskriftif juga dapat diartikan sebagai pengumpulan data sebagai latar alamiah dengan maksud menafsirkan fenomena yang terjadi di mana peneliti sebagai instrument kunci, pengambilan sampel sumber data dilakukan secara purposive dan snowball, teknik pengumpulan dilakukan dengan triangulasi (penggabungan), analisis data dilakukan secara induktif/kualitatif, dan hasil penelitian lebih menekankan pada makna (Anggito dan Setiawan, 2018:8). Adapun yang dijadikan subjek penelitian adalah RPP (Rencana Pelaksanaan Pembelajaran). Data atau hasil tersebut berhubungan dengan proses dalam mendesain RPP daring oleh guru PAI di SD N 1 Pageraji Korwilcam Dindik Cilongok Kabupaten Banyumas yang dikhususkan di kelas IV tahun pelajaran 2020/2021. Oleh 
karena data yang diperoleh berupa informasi tentang desain perencanaan pembelajaran daring, maka teknik pengumpulan data dilakukan dengan wawancara, observasi, dan dokumentasi. Teknik wawancara adalah suatu proses aktivitas medapatkan informasi melalui kegiatan wawancara langsung atau tidak langsung (Sugiyono, 2011). Teknik wawancara ini dilakukan kepada kepala sekolah, guru PAI dan siswa kelas IV. Informasi yang ingin diperoleh dari teknik wawancara ini berupa data-data yang berhubungan dengan kurikulum, metode, media serta hal-hal yang berkaitan dengan pembelajaran PAI. Selain wawancara, data dikumpulkan dengan observasi, yaitu pengamatan langsung atas kelengkapan komponen-komponen yang ada dalam RPP daring yang menjadi fokus penelitian. Penulis mengamati apakah komponen-komponen RPP sudah terpenuhi semua atau belum. Selain itu, dapat menentukan yang menjadi kekuatan dan kelemahan dalam komponen RPP. Untuk mendukung data wawancara dan observasi, dalam penelitian ini juga meneliti dokumen terkait. Dokumen-dokumen yang dimaksud adalah Dokumen 1 Kurikulum 2013, Dokumen Kurikulum Darurat, Prota dan Promes, Silabus, dan RPP.

\section{Hasil dan Pembahasan}

\section{Desain Pelaksanaan Pembelajaran Daring}

\section{Analisis Sistem Perencanaan Pembelajaran}

Perencanaan pembelajaran merupakan sebuah sistem yang mengacu pada ketercapaian tujuan pembelajaran. Secara umum, desain pembelajaran disusun untuk mengefektifkan suatu pembelajaran. Agar siswa dapat belajar sesuai dengan kemampuan masing-masing, maka desain pembelajaran disusun dengan memperhatikan pembelajaran individual peserta didik. Menurut Hakim (2011: 72-73) menyatakan asumsi terkait dengan penyusunan perencanaan pembelajaran di antaranya adalah: (1) Pembelajaran dirancang dalam rangka membantu peserta didik belajar secara individual. Meskipun belajar secara kelompok dalam satu kelas, namun hasil belajar dan kemampuan bersifat individual. (2) Pembelajaran dapat dirancang untuk jangka pendek maupun jangka panjang. Desain jangka pendek berkenaan dengan persiapan pembelajaran untuk materi pembelajaran tertentu. Sedangkan desain jangka panjang berkenaan dengan sejumlah topik yang akan diajarkan untuk jangka waktu tertentu. (3) Sasaran yang ingin dicapai dalam desain/perencanaan pembelajaran adalah siswa belajar.

Berangkat dari asusmsi tersebut, dapat disimpulkan bahwa guru hendaknya membuat rumusan-rumusan tentang apa saja yang akan dilakukan dalam pencapaian tujuan pembelajaran. Rumusan-rumusan yang 
dimaksud merupakan program yang perlu adanya analisis atas semua komponen yang harus saling terkait. Dengan demikian guru harus mempersiapkan perangkat yang harus dilaksanakan dalam merencanakan program. Menurut Hidayat (dalam Majid, 2009:21) menyatakan bahwa perangkat yang harus dipersiapkan dalam perencanaan pembelajaran adalah: (1) memahami kurikulum; (2) menguasai bahan ajar; (3) menyusun program pengajaran; dan (4) menilai program pengajaran dan hasil proses pembelajaran yang telah dilaksanakan.

Berkaitan dengan kurikulum untuk kondisi pandemik seperti sekarang ini tentu tidak sama dengan kurikulum masa sebelumnya. Pada kondisi sekarang ini menuntut adanya kurikulum fleksibel, yakni kurikulum yang dapat dengan mudah menyesuaikan situasi dan kondisi yang tidak menentu dan tidak terduga sebelumnya. Kemendikbud memberikan peluang kepada guru dan kepala sekolah untuk menyesuaikan kurikulum dengan mengidentifikasi materi-materi esensial yang ada di dalam kompetensi dasar di setiap tingkatan sekolah (Gusti, dkk, 2020:89).

Berdasar Surat Edaran Mendiknas, ada 4 hal kebijakan pelaksanaan pembelajaran, yaitu: (1) Pembelajaran mandiri dilakukan untuk memberi pengalaman belajar yang bermakna tanpa dibebani menuntaskan capaian kurikulum untuk kenaikan maupun kelulusan. (2) Para peserta didik harus dibekali dengan kecakapan hidup tentang pandemic Covid-19. (3) Guru memberi tugas secara bervariasi dengan mempertimbangkan kemampuan individu dan fasilitas belajar. (4) Pemberian umpan balik (feedback) terhadap kinerja peserta didik meskipun secara kualitatif. (Mendiknas, 2020)

Kebijakan-kebijakan yang diambil yang tersebut di atas tentunya dengan berbagai pertimbangan yang sangat matang dari para pakar-pakar pendidikan. Dan tentunya disesuaikan dengan tujuan Pendidikan nasional yang bersumber pada nilai Pancasila yang dirumuskan dalam (Kementerian Pendidikan dan Kebudayaan, 2003) pasal 3 yang menyatakan bahwa pendidikan nasional berfungsi mengembangkan kemampuan dan bentuk serta peradaban bangsa yang bermartabat dalam rangka mencerdaskan kehidupan bangsa bertujuan untuk berkembangnya potensi peserta didik agar menjadi manusia yang beriman dan bertakwa kepada Tuhan Yang Maha Esa, berakhlak mulia, sehat, cerdas, berilmu, cakap, kreatif, mandiri, dan menjadi warga negara yang demokratis serta bertanggung jawab. Kurikulum fleksibel yang diterapkan harus mengacu pada tujuan nasional tersebut diharapkan pendidikan akan terus berjalan.

2. Pedoman Perencanaan Pelaksanaan Pembelajaran Daring Berdasar Kurikulum Darurat

Kementerian Pendidikan dan Kebudayaan (Kemendikbud) menerbitkan Pedoman Pelaksanaan Kurikulum pada Satuan Pendidikan 
dalam Kondisi Khusus yang disesuaikan dengan kebutuhan pembelajaran peserta didik. Satuan pendidikan pada kondisi khusus dalam pelaksanaan pembelajaran dapat memilih salah satu opsi, di antaranya adalah: 1. tetap mengacu pada Kurikulum Nasional; 2. menggunakan kurikulum darurat; atau 3. melakukan penyederhanaan kurikulum secara mandiri. Pada kurikulum tersebut dilakukan pengurangan kompetensi dasar untuk setiap mata pelajaran sehingga guru dan siswa dapat memfokuskan pada kompetensi esensial dan kompetensi prasyarat untuk kelanjutan pembelajaran di tingkat selanjutnya.

Pelaksanaan Kurikulum pada Kondisi Khusus bertujuan untuk memberikan fleksibilitas bagi Satuan Pendidikan untuk menentukan Kurikulum yang sesuai dengan kebutuhan pembelajaran Peserta Didik. Pelaksanaan Kurikulum harus memperhatikan usia dan tahap perkembangan peserta didik dan capaian kompetensi pada kurikulum. Serta dilaksanakan dengan berdasarkan prinsip: aktif, relasi sehat antar pihak yang terlibat, inklusif (pembelajaran yang bebas dari diskriminasi Suku, Agama, Ras dan Antar Golongan), keragaman budaya, berorientasi sosial serta masa depan, dan menyenangkan (Kemendikbud, 2020)

\section{Perencanaan Pelaksanaan Pembelajaran PAI Daring}

a. Analisis KI dan KD

Pada bagian atas telah disinggung bahwa, dalam penyusunan kurikulum darurat dilakukan pengurangan kompetensi dasar untuk setiap mata pelajaran sehingga guru dan siswa dapat memfokuskan pada kompetensi esensial dan kompetensi prasyarat untuk kelanjutan pembelajaran di tingkat selanjutnya. Tidak terkecuali pada muatan pelajaran PAI yang dikhususkan pada Kelas IV dalam pembahasan ini. Di dalam penyusunan perencanaan pembelajaran tentunya harus mengikuti pedoman yang telah ditetapkan.

Berdasarkan pengamatan yang dilakukan bersama guru PAI dan tentunya berpedoman pada Buku I tentang Pedoman Penyusunan Tingkat Satuan Pendidikan (KTSP) 2013 kondisi Khusus di SDN 1 Pageraji, Penulis menjumpai perubahan jumlah Kompetensi dasar pada tiap-tiap Kompetensi Intinya. Perubahan tersebut rupanya adanya pengurangan terhadap jumlah KD. Perubahan tersebut, kami uraikan sebagai berikut:

1) Pada KI 1 kompetensi sikap spiritual, jumlah KD pada kurikulum normal berjumlah 21 butir, mengalami penyederhanaan menjadi 13 butir. Adapun KD yang tetap digunakan adalah KD 1.1, 1.2, 1.3, 1.4, 1.6, $1.7, \quad 1.9, \quad 1.10,1.11, \quad 1.13, \quad 1.14, \quad 1.15$, sedangkan KD 1.16-1.21 disederhanakan dalam satu KD. 
2) Pada KI 2 kompetensi sikap sosial, jumlah KD pada kurikulum normal berjumlah 21 butir, mengalami penyederhanaan menjadi 13 butir. Adapun KD yang masih digunakan adalah KD 2.1, 2.2, 2.3, 2.4, 2.6, 2.7, $2.9,2.10,2.11,2.13,2.14,2.15$. Sedangkan pada KD $2.16-2.21$ disederhanakan dalam satu KD.

3) Pada KI 3 kompetensi Pengetahuan, jumlah KD pada kurikulum normal berjumlah 21 butir, mengalami penyederhanaan menjadi 13 butir. Adapun KD yang masih digunakan adalah KD 3.1, 3.2, 3.3, 3.6, 3.7, 3.9, $3.10,3.11,3.13$, 3.14, 3.15. Sedangkan pada KD $3.16-3.21$ disederhanakan dalam satu KD.

4) Pada KI 3 kompetensi Pengetahuan, jumlah KD pada kurikulum normal berjumlah 21 butir, mengalami penyederhanaan menjadi 13 butir. Adapun KD yang masih digunakan adalah KD 4.1, 4.2, 4.3, 4.6, 4.7, 4.9, $4.10,4.11,4.13,4.14,4.15$. Sedangkan pada KD 4.16 - 4.21 disederhanakan dalam satu KD.

Dari temuan tersebut, tentu akan dijadikan dasar dalam mendesain RPP PAI daring untuk memfokuskan KD-KD yang diutamakan.

b. Komponen-komponen Perencanaan Pembelajaran Daring

Kurikulum menurut Sudrajat (dalam Gusti, 2020: 87), mempunyai 5 komponen utama, yaitu:

1) Tujuan pembelajaran, merupakan target atau sasaran yang hendak dicapai dalam kurun waktu yang ditentukan, misalnya untuk satu kali tatap muka atau bahkan satu semester.

2) Isi bahan, berisi tentang materi kurikulum yang dikembangkan dan disusun berdasarkan pada pencapaian tujuan pelajaran dan bahan kajian atau topik-topik pelajaran yang dapat dikaji oleh siswa.

3) Strategi pembelajaran, dalam pelaksanaan pembelajaran strategi atau metode dan teknik pembelajaran saat ini lebih berpusat pada peserta didik. Mereka secara aktif menentukan materi dan tujuan belajarnya sesuai dengan minat dan kebutuhannya.

4) Organisasi kurikulum. Keragaman dalam mengorganisasikan pengembangan kurikulum didasari oleh pandangan yang mendasari.

5) Evaluasi, dimaksudkan untuk mengukur tingkat ketercapaian tujuantujuan pembelajaran dan tujuan Pendidikan pada umumnya.

Dari komponen-komponen yang disebutkan di atas yang kemudian akan dikembangkan dalam perangkat pembelajaran di antaranya adalah Prota, Promes, Silabus, Rencana Pelaksanaan Pembelajaran (RPP) dan media pembelajaran serta instrument evaluasi. 


\section{c. Perangkat Pembelajaran Pendukung RPP}

Dalam penelitian ini, penulis menyandingkan beberapa perangkat pembelajaran selain RPP. Hal ini bermaksud agar terjadi kesesuaian antar perangkat pembelajaran yang lain dengan RPP yang akan didesain. Perangkat pembelajaran yang dimaksud, antara lain:

1) Prota (Program Tahunan dan Promes Program Semester)

Prota dan promes yang telah disusun oleh guru PAI SDN 1 Pageraji di Kelas 4, telah memuat identitas sekolah dengan lengkap. Mencamtumkan KI, KD, Indikator Pencapaian Kompetensi (IPK), tujuan pembelajaran dan materi pembelajaran. Prota dan promes yang telah disusun sudah disesuaikan dengan kurikulum darurat, yakni dengan melakukan penyederhanaan KD pada tiap-tiap KI.

2) Silabus

Data yang diamati dari dari dokumen silabus adalah langkahlangkah, metode, serta media yang tercantum dalam menyusun Silabus. Hasil yang diperoleh sebagai berikut:

a) Menuliskan identitas silabus

Identitas terdiri atas nama sekolah, muatan pelajaran, kelas dan semester. Guru PAI telah menuliskan identitas dengan lengkap.

b) Menuliskan KI dan KD

KI dan KD dituliskan dimaksudkan agar siswa memiliki orientasi ke masa depan. Selain itu agar peserta didik memiliki sikap terbuka terhadap keanekaragaman informasi yang hadir di sekitarnya.

c) Materi pembelajaran

Materi pembelajaran ditentukan dengan cara mengidentifikasi materi pembelajaran yang menunjang dan relevan dengan kompetensi dasar yang hendak dicapai dengan mempertimbangkan: (1) Kondisi darurat saat ini. (2) Relevansi dengan karakteristik daerah, kepentingan local, nasional serta global. (3) Kebermanfaatan bagi siswa dan kebutuhan siswa. (4) Alokasi waktu

d) Kegiatan pembelajaran

Kegiatan pembelajaran dirancang untuk memberikan pengalaman belajar yang melibatkan proses mental dan fisik melalui interaksi antar peserta didik, guru serta lingkungannya. Pada kondisi pandemic saat ini, kegiatan pembelajaran tidak lagi seperti biasanya. Guru dalam menyusun rencana pembelajaran harus disesuaikan dengan kondisi yang ada. Berbagai 
Langkah-langkah serta perangkat pendukung harus dipikirkan dan dipersiapkan matang-matang.

e) Indikator

Indikator diperlukan untuk mengukur hasil belajar peserta didik tentang penguasaan sikap, pengetahuan dan ketrampilan peserta didik.

f) Evaluasi

Evaluasi merupakan serangkaian kegiatan untuk memperoleh, menganalisis, dan menafssirkan data tentang proses dan hasil belajar bagi peserta didik. Ada 3 komponen yang harus diperhatikan, yaitu: (1) Teknik evaluasi. (2) Bentuk instrument. (3) Contoh instrument.

g) Alokasi Waktu

Alokasi waktu yang dicantumkan dalam silabus merupakan perkiraan waktu untuk menguasai kompetensi dasar yang dibutuhkan siswa. Penentuan alokasi waktu pada setiap kompetensi dasar didasarkan pada: (1) Jumlah minggu efektif. (2) Alokasi waktu muatan pelajaran per minggu. (3) Memperhatikan jumlah kompetensi dasar, keluasan, kedalaman dan tingkat kesulitan.

h) Sumber Belajar

Sumber belajar merupakan segala sesuatu atau objek dan atau bahan yang diperlukan dalam kegiatan pembelajaran, dapat berupa buku teks, media cetak, media elektronik, narasumber, lingkungan sekitar.

4. Desain Perencanaan Pelaksanaan Pembelajaran Daring di SD N 1 Pageraji Kelas IV pada Pembelajaran 6

Pada prinsipnya, mendesain atau membuat rancangan perencanaan Pembelajaran pada masa pandemic ini sama dengan kurikulum normal. Hanya saja dalam penyusunan kurikulum darurat bersifat fleksibel. Penyusunan perangkat pembelajaran di masa pandemik ini tentu saja disesuaikan dengan kurikulum darurat yang telah ditetapkan oleh pemerintah, seperti yang telah diuraikan dalam Keputusan Menteri Pendidikan dan Kebudayaan Republik Indonesia Nomor 7L91/P/2020 Tentang Pedoman Pelaksanaan Kurikulum pada Satuan Pendidikan Dalam Kondisi Khusus.

Rencana Pelaksanaan Pembelajaran yang menjadi objek penelitian ini, difokuskan pada pelaksanaan pembelajaran 2 dengan Tema membaca Q.S Al-Falaq. Secara teknis, seorang guru harus memahami format dalam kegiatan penyusunan RPP, mengingat sering kali terjadi perubahan. Berdasarkan pengamatan dan wawancara yang dilakukan penulis terhadap 
RPP yang disusun oleh guru PAI SDN 1 Pageraji di Kelas IV yang disesuaikan dengan kurikulum darurat, diperoleh hasil sebagai berikut:

a. Menuliskan kolom identitas dengan tepat.

Kolom identitas yang dituliskan di RPP berisi nama sekolah, kelas dan semester, tema dan subtema, muatan pelajaran, dan alokasi waktu. Berdasarkan data yang disajikan, guru PAI telah menuliskan data tersebut dengan lengkap dan benar.

b. Menentukan tujuan pembelajaran

Tujuan pembelajaran ditulis sesuai dengan KI dan KD yang ada. Tujuan pembelajaran pada Tema membaca Q.S Al-Falaq yaitu: (a) Melalui pembelajaran jarak jauh menggunakan aplikasi google meet/whatsapp dan bantuan modul pembelajaran peserta didik dapat menyebutkan jumlah ayat Q.S Al Falaq dengan benar. (b) Melalui pembelajaran jarak jauh menggunakan aplikasi google meet/whatsapp dan bantuan modul pembelajaran peserta didik dapat menuliskan makna QS Al Falaq dengan benar.

Dalam tujuan pembelajaran di atas tercantum aplikasi google meet/whatsapp, ini artinya dalam penyampaian materi menggunakan kedua media tersebut.

c. Menentukan kegiatan pembelajaran

Pada kolom kegiatan pembalajaran menguraikan langkah-langkah pembelajaran daring yang dilakukan, dengan menyertakan media serta metode yang disesuaikan dengan kegiatan pembelajaran. Proses pembelajaran yang dilaksanakan di kelas 4 ini menggunakan metode yang bervariasi disesuaikan dengan tingkat berpikir peserta didik dan tingkat kemampuan peserta didik dan orang tua dalam mengkakses internet. Begitu pula untuk media pembelajaran yang digunakan juga bervariasi. Media online yang sering digunakan oleh guru misalnya dengan Google Class Room, WhatsApp. Namun tidak menutup kemungkinan juga guru membuka program konsultasi terprogram dengan cara online maupun tatap muka.

Aplikasi Google Class Room (GCR) menjadi media pilihan utama dalam pelaksanaan pembelajarn daring, sebab dirasa cukup efektif. Guru dapat bertatap muka secara langsung dan berkomunikasi layaknya seperti biasa walaupun melalui virtual. Dengan demikian, akan terjadi interaksi langsung. Cara penggunaannya pun mudah. Sedangkan aplikasi WhatsApp, ini digunakan sebagai alternatif bila ada kendala teknis dalam penggunaan $G C R$ dan media di luar pembelajaran. 
Adapun data hasil pengamatan dan wawancara dari proses desain RPP yang diperoleh adalah sebagai berikut:

1) Kegiatan pendahuluan

Melalui aplikasi google class room/Whatsapp, guru membuka salam, dilanjutkan dengan doa bersama, memberikan motivasi, menyampaikan tujuan pembelajaran, skenario pembelajaran dan aspek-aspek yang akan dinilai.

2) Kegiatan Inti

a) Peserta didik mengunduh bahan bacaan yang telah diberikan mengenai bacaan dan makna QS al Falaq yang telah di-share oleh guru melalui aplikasi Whatsapp.

b) Peserta didik dan guru berdiskusi mengenai materi melalui GCR.

c) Peserta didik mengerjakan tugas dan kuis mengenai makna yang terdapat pada QS. al-Falaq

3) Kegiatan Penutup

Pada kegiatan penutup, peserta didik mengerjakan tes akhir dan mengisi penilaian diri melalui aplikasi google form yang telah dirancang oleh guru. Selanjutnya membuat kesimpulan dan tindak lanjut dengan memberikan tugas rumah.

d. Menentukan penilaian

Penilaian yang dilakukan oleh guru meliputi sikap spiritual menggunakan Pengamatan selama daring dan lembar penilaian diri, pengetahuan dengan menggunakan tugas pada modul, quiziz, tes akhir pada google form, sedangkan penilaian ketrampilan dilakukan dengan cara online dengan menggunakan media online misalnya dengan video call.

Dari uraian langkah-langkah yang dilaksanakan oleh guru PAI dalam mendesain RPP, penulis berhasil menginventarisir data-data yang menjadi kelebihan dan kelemahan dalam proses desain RPP tersebut.

Adapun kelebihannya adalah: (a) Desain pembelajaran yang dirancang secara daring menggunakan media berbasis internet, hal ini menguntungkan pada semua pihak bagi guru maupun peserta didik untuk lebih melek terhadap IT, apalagi di zaman yang semakin modern seperti saat ini. (b) Dengan kemampuan IT yang dimiliki, akan mengarahkan guru untuk lebih berinovasi dalam pembelajaran dalam masa-masa yang akan datang.

Sementara kelemahan dari RPP daring ini, adalah: (a) Karena semua berbasis internet, tentu saja guru dan peserta didik memerlukan perangkat 
teknologi yaitu $H P$ yang memadai agar dapat melaksanakan pembelajaran dengan baik. Sementara, tidak semua peserta didik memilikinya. Tentu ini akan menjadi kendala dalam keberlangsungan proses pembelajaran. (2) Membutuhkan biaya untuk pengadaan kuota. Meskipun ada program bantuan kouta bagi guru dan peserta didik, namun ternyata tidak semua guru dan peserta didik dalam satu sekolah menerimanya. (3) Lebih banyak menyita waktu untuk mempersiapkan RPP. Dalam RPP daring, guru lebih sering membuat video pembelajaran terlebih dahulu. Langkah ini ditempuh agar nantinya dalam proses pembelajaran akan lebih menarik perhatian peserta didik. Untuk membuat video pembelajaran membutuhkan waktu yang cukup lama, mulai dari proses pengambilan gambar, proses menyunting kemudian mengedit sampai dengan diperoleh video yang bagus dan layak.

\section{Kesimpulan}

Keberhasilan suatu proses pembelajaran tentunya diawali dengan perencanaan yang sangat matang. Hal ini diperuntukkan agar proses pembelajaran tersusun dan terarah sesuai dengan tujuan pembelajaran yang akan dicapai dalam sebuah satuan pendidikan. Di saat pendidikan dalam masa pandemik akibat Covid-19 seperti sekarang ini dirasa sangat menyulitkan bagi semua komponen pembelajaran. Sementara itu pemenuhan hak peserta didik untuk mendapatkan layanan pendidikan merupakan kewajiban bagi seluruh komponen satuan pendidikan. Melalui keputusan Menteri Pendidikan dan kebudayaan, pemerintah mengupayakan kurikulum darurat sebagai alternatif cara mengatasi kesulitan dalam melakukan proses pembelajaran. Guru dituntut untuk meningkatkan kemampuan dalam penguasaan materi, metode, dan media pembelajaran agar dapat mencapai tujuan pendidikan yang telah ditentukan. Jika pelaksanaan tidak direncanakan dengan baik, dapat berakibat pada menurunnya kualitas pendidikan.

Dampak dan permasalahan tersebut terjadi pada setiap mata pelajaran, tidak terkecuali mata pelajaran Pendidikan Agama Islam yang merupakan mata pelajaran utama yang banyak melibatkan pemahaman konsep dan praktik. Dari kondisi nyata yang terjadi tersebut, menjadi dasar pertimbangan bagi pendidik khususnya di SDN 1 Pageraji untuk membuat rancangan pembelajaran PAI daring dengan berdasar pada Kurikulum Darurat yang kini telah diberlakukan. RPP didesain sedemikian teliti dan tepat agar seluruh peserta didik dapat belajar dengan baik, serta lebih mudah bagi orang tua dalam mendampingi anak-anak mereka dalam belajar. Dari desain RPP yang telah disusun, terdapat beberapa kelebihan sekaligus kelemahan. Dari beberapa kelebihan tentunya akan menjadi dasar 
bagi guru untuk selalu berinovasi dalam dunia Pendidikan, sementara kelemahan yang terdapat di dalamnya akan dicari solusi yang terbaik demi keberlangsungan proses pembelajaran yang baik, khususnya di SD N 1 Pageraji.

\section{DAFTAR PUSTAKA}

Anggito, Albi dan J. Setiawan. (2018). Metodologi Penelitian Kualitatif. Sukabumi: PT Jejak.

Isnawardatul. (2017). Efektifitas Perencanaan Pembelajaran dalam Pembelajaran Pendidikan Agama Islam di Sekolah. Jurnal Muddarisuna. P-ISSN: 2089-5127 E-ISSN: 2460-0733. Volume 7, Nomor 1, Januari-Juni 2017.

Farida. (2019). Perencanaan Pembelajaran. Medan: UIN Sumatra Utara.

Gusti, Sri, dkk. (2020). Belajar Mandiri Belajar Mandiri di Tengah Pandemi Covid-19. Konsep, Strategi, Dampak dan Tantangan. Yayasan Kita Menulis.

Hakim, Lukmanul. (2011). Perencanaan Pembelajaran. Bandung: CV Wacana Prima.

Hidayat, Tatang dan Makhmud Syafe'i. (2018). Filsafat Perencanaan Dan Implikasinya Dalam Perencanaan Pembelajaran Pendidikan Agama Islam Di Sekolah. Jurnal: Lentera Pendidikan, Vol. 21 No. 2 Desember 2018: 188-205

Keputusan Menteri Pendidikan dan Kebudayaan Republik Indonesia Nomor 7 L91/P/2020 Tentang Pedoman Pelaksanaan Kurikulum pada Satuan Pendidikan Dalam Kondisi Khusus.

Mahmudi. Pendidikan Agama Islam Dan Pendidikan Islam Tinjauan Epistemologi, Isi, Dan Materi. Ta'dibuna: Jurnal Pendidikan Agama Islam, Vol. 2, No. 1, Mei 2019.

Majid, Abdul. (2009). Perencanaan pembelajaran. Bandung: PT Remaja Rosdakarya.

Nafis, M. Muntahibun. (2011). Ilmu Pendidikan Islam. Sleman: Teras.

Sugiyono. (2010). Metode Penelitian Kuantitatif Kualitatif dan R dan D. Bandung: Alfabeta.

Sukmadinata, N. Syaodih. (2006). Pengembangan Kurikulum teori dan Praktek. Bandung: Remaja Rosda karya. 
---_---. (2010). Metode Penelitian Pendidikan. 2020. Bandung: Rosdakarya. 